\title{
NON-AGENDA
}

With the view of causing an increase to take place in the mass of national wealth, or with a view to increase of the means either of subsistence or enjoyment, without some special reason, the general rule is, that nothing ought to be done or attempted by government. The motto, or watchword of government, on these occasions, ought to be - Be quiet. . . Whatever measures, therefore, cannot be justified as exceptions to that rule, may be considered as non-agenda on the part of government.

_- Jeremy Bentham (c.1801)

\section{Not the Negative Income Tax Again!}

\section{James Cox}

$\mathrm{U}$

Tntil recently, I had thought that the negative income tax was one of the fashions of the 1960s and 1970s which has since been abandoned in the sober light of subsequent experience. In particular, experiments in the United States, which facilitated an investigation of the effects of replacing the existing welfare system by a more generous one, showed that the negative income tax reduced hours of work, especially by wives and younger men, and increased rates of marital instability. ${ }^{1}$

The idea now seems to be making a comeback. In a recent article, Professors Peter Dawkins and John Freebairn (1997) discuss the reasons for the increase in unemployment since the 1960 s and what might be done to reduce the level of unemployment. They conclude that further product-market reform and lower real wages, especially for the less skilled, are required. Since the labour market is unlikely (in their view) to be significantly reformed in the near future, consideration should be given to reducing award wages. Dawkins and Freebairn believe that the Industrial Relations Commission is more likely to agree to this if those receiving reduced award wages can be compensated through the tax and transfer systems. They suggest that a tax credit (or negative income tax program) that takes family circumstances into account could compensate low-wage earners for reduced award

I See Murray (1984:147-53) and Munnell (1987) for further discussion.

James Cox is a member of the Independent Pricing and Regulatory Tribunal of New South Wales. 
wages. The introduction of earned income tax credits might, however, be considered as an interim measure.

In a related publication, Dawkins et al. (1997) investigate alternative negative income tax proposals. They argue that a simple negative income tax could improve incentives by replacing the many complex and overlapping means tests that now exist in Australia. The simplest negative income tax involves providing tax credits to all adults, which are increased for those who have children or pay high rents to private landlords. The tax credits and any private income are then added together and taxed at a constant rate. Low-income individuals (for whom tax credits exceed tax payable) will receive a payment from the government, but higher-income individuals will be required to make a payment.

These authors also investigate more complex versions of the negative income tax, in which tax credits are phased out as income increases; some people receive a reduced guaranteed income (or none at all); or supplements are paid to persons who are eligible to receive social security benefits. These modified versions are less expensive than the pure negative income tax, but they retain some of the complexity of the present tax and transfer arrangements.

Finally, Dawkins et al. cost their alternative negative income tax proposals on the assumption that behaviour would not change following introduction of the program. They proceed by postulating a system of tax credits and then calculating the flat tax rate that would be required to finance both the tax credits and the non-social security expenditure of government. The required tax rates are in the range 45-57 per cent. The pure negative income tax option requiring a tax rate of 45 per cent involves 'the reduction of the income of social security beneficiaries by about 25 per cent' (Dawkins et al., 1997:9). The required reduction in social security incomes would be less if a more selective approach to providing assistance were adopted.

There are naturally many ways in which one might choose to evaluate these arguments. I think it is useful to do so by considering the following questions:

1. How successful are the negative income tax proposals in providing further assistance to low-wage earners, thus (according to Dawkins and Freebairn) making reduced award wages more acceptable to the Industrial Relations Commission?

2. Given that the negative income tax proposals reduce effective tax rates for some individuals but increase them for others, are they likely on balance to result in an improvement or a worsening in the incentives to earn additional income?

3. To what extent are the negative income tax proposals consistent with other proposals for the reform of social security, which emphasise defining and then enforcing the reciprocal obligations which beneficiaries incur in return for receiving benefits? 
4. What can be said, particularly in the light of the experiments in the United States, about the possible unintended consequences of introducing a negative income tax?

Some comments follow on each of these points.

\section{Targeting}

The main issue here is that, while low wages are earned by individuals, low income in relation to their needs is a problem for all members of a family or a household. Most families or households share incomes to some extent, even if they do not do so with complete fairness. Many people who earn low wages belong to families whose total income is adequate: they may, for example, be secondary earners or sons or daughters just starting employment. By contrast, a single-income family with high needs may experience difficulties even though the sole earner's wage rate, considered in isolation, is adequate. Indeed, these difficulties may result from the limited extent of the family's participation in the labour market rather than from low wages. The relationship between low wages and low family income is therefore probably not a close one. One feels that this point needs to be made carefully to the Industrial Relations Commission. Regrettably, however, Dawkins et al. do not investigate the extent of correlation between low wages and low family incomes.

Low-income families in employment with children, and those paying high rents to private landlords, already receive considerable government assistance. The negative income tax proposals would extend assistance to similar families with higher incomes. This would not do much to address any problem of family poverty that might be worsened as a result of lower award wages.

Dawkins et al. provide tables showing the distributional consequences of their proposals for families classified according to their private (non-benefit) income. The distributional impacts of the various proposals differ substantially. As a general rule, they tend to increase incomes at the bottom end of the distribution of family private incomes and to reduce incomes at the top end. ${ }^{2}$ Income survey data from the Australian Bureau of Statistics (1997:12-13, Table 1) suggest that there are relatively few employed persons in families within the bottom three deciles of the family gross income distribution. This is likely to be even more true of the private income distribution, which excludes government benefits. The negative income tax proposals seem unlikely, therefore, to be efficient in providing additional assistance to families which include low-wage earners.

\section{Incentives}

Dawkins et al. discuss the incentive effects of their proposals in terms of changes to the effective marginal rates arising from the interaction of the tax and social security

\footnotetext{
${ }^{2}$ Exceptions are option lb (a reduction in the income guarantee below the age pension level) and option 2 (a reduced income guarantee plus tax credits which are tapered out as income increases).
} 
systems. ${ }^{3}$ They suggest that a flat marginal rate of 45 per cent is a sensible target in the early stages. This is below the top rate of income tax and also below the effective rate experienced over the income range where benefits are abated. Moreover, they argue that many of those who would experience lower effective marginal tax rates under their proposals (for example, women who are thinking about undertaking part-time work) are likely to be particularly responsive to incentives.

Although some individuals pay income tax at the top marginal rate, the majority either pay no tax at all (because income is below the tax threshold) or pay tax at a rate substantially below the top marginal rate. To gain an impression of the overall effects of introducing a negative income tax, one may compare the 4.5 per cent flat tax with an average of the marginal tax rates arising from the existing arrangements. One might, for example, calculate a person-weighted average marginal tax rate. (This shows how much would be taken in increased tax on average if all taxpayers increased their taxable incomes by one dollar.) This average marginal tax rate can be estimated from taxation statistics to have been 25.4 per cent in 1994/95 (Australian Taxation Office, 1996). ${ }^{4}$ In addition, the effect of withdrawal of meanstested assistance needs to be considered. This raises the average marginal tax rate to about 28 per cent. 5

The difference between the tax rates of 45 per cent and 28 per cent indicates that significantly more redistribution than at present would be undertaken were the negative income tax proposals to be implemented. This would tend to have adverse implications for incentives. (Alternatively, the basic income guarantee could be reduced below the age pension level still further; this would however reduce the attractiveness of the negative income tax proposals.)

Dawkins et al. argue that those who experience lower tax rates as a result of the introduction of negative income tax (for example, sole parent pensioners who work part-time) are particularly likely to increase their hours of work. The overall incentive effects of introducing a negative income tax may therefore be favourable in their view. However, many of those who would experience higher effective tax rates as a result of the negative income tax (for example, women in two-parent families who are contemplating part-time work) may also be particularly sensitive to incentives. In addition, there are many relevant margins other than the choice between leisure and work that would be affected by the introduction of the negative income tax. Dawkins et al. (1997:27) promise us 'forthcoming theoretical simulations' to demonstrate the favourable consequences of introducing a negative income tax for incentives. In the absence of these simulations it seems safest to conclude that the

\footnotetext{
${ }^{3}$ It is important to note that income effects (arising, for example, from the extension or withdrawal of assistance) are also relevant.

${ }^{4}$ This is the average marginal rate for both non-taxable and taxable individuals. Alternatively, an income-weighted marginal tax rate could be calculated, which would be higher.

${ }^{5}$ This assumes that 5 per cent of individuals have effective tax rates 50 percentage points higher than would otherwise be the case (Dawkins et al., 1997:6).
} 
higher effective marginal tax rates (on average) resulting from the negative income tax programs would on balance weaken, rather than strengthen, incentives.

\section{Reciprocal Obligations}

The introduction of the negative income tax would reverse the trend towards tighter targeting of welfare that has occurred in recent years. Assessment of entitlement to welfare would be based almost entirely on private income. Private income may be too easily subject to manipulation by recipients to be the entire basis for welfare policy. The negative income tax is contrary to the increasing tendency for beneficiaries to be required to perform certain reciprocal obligations in return for receiving benefits. For example, unemployment beneficiaries in Australia are required to be looking for full-time work and may, in addition, be required to work part-time while receiving benefit. There seems to be a good deal of public support for introducing new obligations for certain beneficiaries.

\section{Unintended Consequences}

It is easy to contrast the imagined simplicity of a new system, such as negative income tax, with the messy reality of our existing taxation and social security arrangements. Nevertheless, the complexity is there for a purpose, namely, to keep the cost of providing adequate assistance to those who need it within reason. It will not be easy for governments to dispense with this complexity.

Those who believe that further deregulation of the labour market is desirable should argue for that directly. Although the political climate may seem unfavourable, this can quickly change. It is getting things the wrong way round to argue for far-reaching and probably irreversible changes to our social arrangements, the consequences of which can be foreseen only dimly, to remove what may be only temporary difficulties. It is, moreover, simple-minded to argue that labour market deregulation will necessarily lead to lower wages since other aspects of the employment contract (such as non-wage benefits and the organisation of work) would also vary.

One effect of introducing the negative income tax would be to make government assistance available in many circumstances where it is not at present. Although it takes time for behaviour to change, experience suggests that many more people eventually qualify for benefits than was expected at the time of introduction of the benefit. For example, the number of sole parent pensioners in Australia today far exceeds earlier expectations. The unintended consequences of the negative income tax experiments in the United States have already been noted. All this indicates that governments need to be very cautious indeed about extending assistance to new groups of beneficiaries.

By contrast to the negative income tax, Dawkins and Freebairn's alternative proposal for the introduction of an Earned Income Tax Credit is likely to direct additional assistance to persons earning low wages. But there already is a multiplicity of programs for low-income families in employment (such as parenting allow- 
ance, family payment and family tax payment). Worries about complexity and disincentive effects will therefore limit what more can be done here.

\section{References}

Australian Bureau of Statistics (1997), Income Distribution, Australia, 1995-96, AGPS, Canberra.

Australian Taxation Office (1996), Taxation Statistics, 1994.95, AGPS, Canberra

Dawkins, P. \& J. Freebain (1997), 'Towards Full Employment', Australian Economic Review 30: 40517.

Dawkins, P., G. Beer, A. Harding, D. Johnson \& R. Santella (1997), Towards a Negative Income Tax System, Melbourne Institute of Applied Economic and Social Research, University of Melbourne.

Munnell, A. (ed.) (1987), Lessons from the Negative Income Tax Experiments, Federal Reserve Bank of Boston and Brookings Institution, Boston.

Murray, C. (1984), Losing Ground: American Social Policy, 19501980, Basic Books, New York. 